\title{
【論文】
}

\section{炭化・過熱水蒸気処理・爆砕による木質バイオマスの 化学成分変化に関する研究}

\author{
松 永 安希子*.大西 龍 ${ }^{* *}$. 入 江 満 美* \\ 山口武 則**牛久保明 邦*
}

【要 旨】 木質バイオマスを原料とした炭化・過熱水蒸気処理・爆砕などの処理技術が提案されている

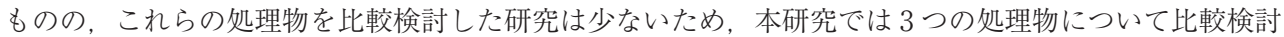
した。温度 $400^{\circ} \mathrm{C}$ 処理時間 60 分で炭化した場合, アルコール・ベンゼン抽出物とホロセルロースの分 解が進み, 固定炭素が増加し, 質の高い有効な燃料が製造できる。しかし, 爆砕・過熱水蒸気処理に比 べて，炭素の損失が極めて大きい処理であることが示された。蒸気温度 $200^{\circ} \mathrm{C}$ ，処理時間 60 分の過熱 水蒸気処理と爆砕に扔いて, 広葉樹を原料とした場合, アルコール・ベンゼン抽出物が増加し, ホロセ ルロースの一部が分解された。

過熱水蒸気処理は, 固定炭素量が増加し，発熱量も高くなるが，炭化処理をした木材ほど燃料として の質は高くない。しかし，樹木中の炭素を有効に利用する場合，過熱水蒸気処理は炭素の損失が少なく， 適していると考えられる。

キーワード: 炭化, 過熱水蒸気処理, 爆砕, 木質バイオマス, 炭素収支

\section{1. は じめに}

現在，日本は枯渴が予測される石油等の海外の化石燃 料に依存した,「大量生産・大量消費・大量廃棄」の社 会システムにより地球温暖化等の環境問題が深刻化して いる。これにより生態系や人類活動への悪影響などさま ざまな問題が懸念されており, いかにして化石燃料の消 費を減らすかは世界的な課題となっている。この対策と して, わが国では, 2002 (平成 14) 年 12 月にバイオマ ス・ニッポン総合戦略が閣議決定され，バイオマス資源 を最大限有効にエネルギーや製品として総合的に利活用 するバイオマス利用促進が打ち出された。その中でも, 林地残材や建築廃材など木質バイオマスはその利用率が

原稿受付 2009.9.14 原稿受理 2010.12.27

* 東京農業大学国際食料情報学部国際農業開発学科

***阪府立大学生命環境科学研究科,

$\mathrm{NPO}$ 法人 エコデザインネットワーク

連絡先： ₹ 156-8502 東京都世田谷区桜丘 1-1-1

東京農業大学国際食料情報学部国際農業開発学科
低く, 現在, 国内で伐木されている量は 1,150 万 ton/年 であり,このうち 400 万 ton/年が利用されることなく 林地に残されていると報告されている11。よって, 未利 用な木質バイオマスをエネルギーや製品として利用する ことが期待されている。木質バイオマスは，さまざまな 前処理が行われた後, 暖房 ·調理用の燃料や, 活性炭, 工業用, 土壤改良用, 家畜試料添加用, 床下調湿用など として利用されていたり，またはその利用が期待されて いる。また特に炭化をした木質バイオマスの利用は, 土 壤改良用が全体の約 4 割 $^{2}$ を占めている。

現在，木質バイオマスの前処理方法としては，炭化· 過熱水蒸気処理・爆砕などが注目されている。特に, 炭 化については多くの研究が行われてきたが, 過熱水蒸気 処理・爆砕についての研究は多くはなく, これら 3 つの 処理方法はそれぞれの一部が似た技術であるにも関わら ず, 処理後の試料を化学的に比較検討した研究は少ない。 そこで, 本研究ではこれら 3 つの処理によって木質バイ オマスがどのように化学的な変化するのか明らかにする とともに, 3 つの処理物の化学的比較検討を行うことを 目的とした。 


\section{2. 炭化・過熱水蒸気処理・爆砕の概要}

炭化とは無酸素あるいは低酸素状態で有機物を分解し， 炭素に富んだ物質にする技術である ${ }^{3)}$ 。炭化物である木 炭は, 多孔質で軽量, アルカリ性といった特徴を持ち, 吸着材, 水質浄化材や床下調湿材, そして昔ながらの燃 料用として利用されている。

過熱水蒸気とは操作圧力下で沸騰気化した水（飽和水 蒸気）をさらに加熱して沸点以上の温度とした完全に気 体状態の水を意味し, 過熱水蒸気処理はこれを用いて木 材を処理する方法である4)。一般に過熱水蒸気はほぼ無 酸素状態での熱処理が可能であり, バイオマスを酸化さ せずに分解・炭化させることができることから関心が高 まっている。現在, 過熱水蒸気処理は食品の殺菌, 住宅 用木材の乾燥や污泥の乾燥などに使用され，または，こ れらの目的のために研究がなされている。

爆砕は $100 \sim 300^{\circ} \mathrm{C}, \quad 1 \sim 90$ 気圧の高温・高圧の水蒸気 にて 1 60 分間処理後, 直ちに減圧することにより, 水 蒸気を膨化させ，木材の組織を崩壊・纎維化させる技術 である。有用物質の抽出によく用いられ, 利用方法とし ては, 飼料化, アルコール化などがある。爆砕法に関す る総説は棚橋5によって報告されているが, まだ研究過 程にある。

以上の上うに，これまでに木質バイオマス有効利用の ためのさまざまな処理技術が提案されているが, 炭化と 過熱水蒸気処理は無酸素もしくは低酸素状態で処理を行 うため，炭化させることができる技術である。過熱水蒸 気処理と爆砕の違いは圧力を一気に解放するか, 徐々に 解放するかの違いである。

\section{3. 実 験 方 法}

\section{1 実験装置}

\section{1 .1 炭 化}

図 1 に試験に使用した炭化装置を示す。炭化のプロセ スは次の通りである。ステンレス製容器に試料を量り, 電気炉内へ設置し, $21^{\circ} \mathrm{C} / \mathrm{min}$ で昇温し, 温度が $400^{\circ} \mathrm{C}$

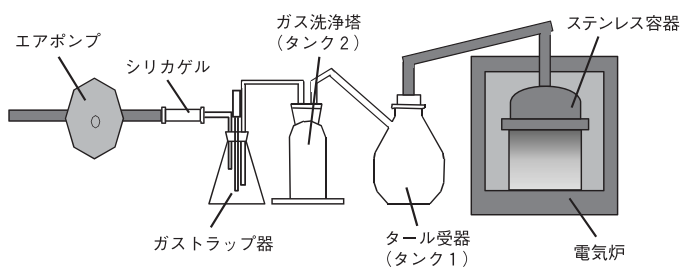

図 1 炭化装置の概要
に達した後，60 分間 $400^{\circ} \mathrm{C}$ を維持した。炭化中，図中に 示すエアポンプによって, ステンレス容器内より発生す る気化ガスを強制的に吸引し, 容器内を酸素希薄状態と することによって炭化を行った。発生する気化ガスは, ステンレス容器から, ガラス管, タンク 1 , タンク 2 , ガストラップ器, シリカゲルカラム, エアポンプの順で 通過し，ドラフト内へ排気した。タンク 1 およびタンク 2 は冷却温度 $5 \sim 10^{\circ} \mathrm{C}$ で冷却を行い, 液化物（粗木酢液, 木タールの混合液) を得た。タンク 2 には, 蒸留水を充 填し，水中にガスを流入することによって，ガス成分の 凝縮化を促し, タンク 1 では回収しきれない成分を回収 した。

\section{1 .2 過熱水蒸気処理}

本研究に用いた装置は, 反応部となる改質炉および水 蒸気生成のためのボイラー（SUS304 製, 有効容積 $0.063 \mathrm{~m}^{3}$ ) から構成されている。過熱水蒸気処理装置の 概要を図 2 に示した。過熱水蒸気処理のプロセスは, 次 の通りである。試料を改質炉に投入し，ボルトによって 炉の蓋を密閉する。水道水を軟化器で軟水化し, 脱気夕 ンクに送水・貯水し, ボイラーへ供給された一定量の軟 水が加熱後に水蒸気となり気水分離器へと送気され, 水 蒸気と水に分離後, 高温水蒸気が改質炉に送られ，60 分間処理後, 徐々に圧力を開放し, 炉内の圧力が大気と 同じになった後，ボルトを緩め炉の蓋を開け試料を回収 した。

\section{1 .3 爆 砕}

図 3 に爆砕装置を示した。本研究で用いた爆砕装置は, 反応部となる爆砕缶および水蒸気生成を行うボイラーか ら構成されている。爆砕のプロセスは, 試料を爆砕缶に 投入後, 水道水を軟化器で軟水化し, 脱気タンクに送 水・貯水し, ボイラーへ供給された一定量の軟水が加熱 後に水蒸気となり気水分離器へ送気され, 水蒸気 (気 体）と水（液体）に分離後, 爆砕缶へ送られる。爆砕缶 に送られた高圧の水蒸気にて試料を 60 分間処理後, 直 ちに爆砕缶をあけ減圧し，破砕された試料を回収した。

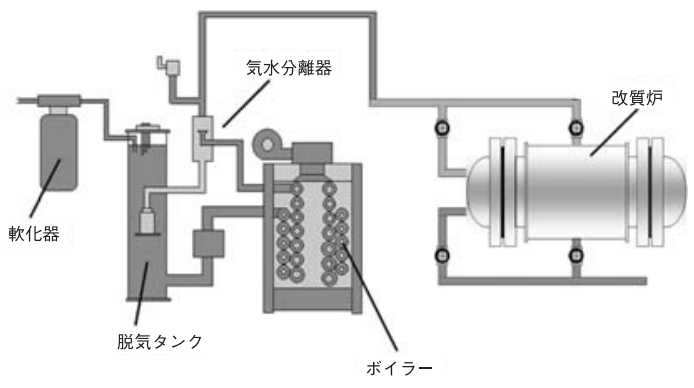

図 2 過熱水蒸気処理装置の概要 


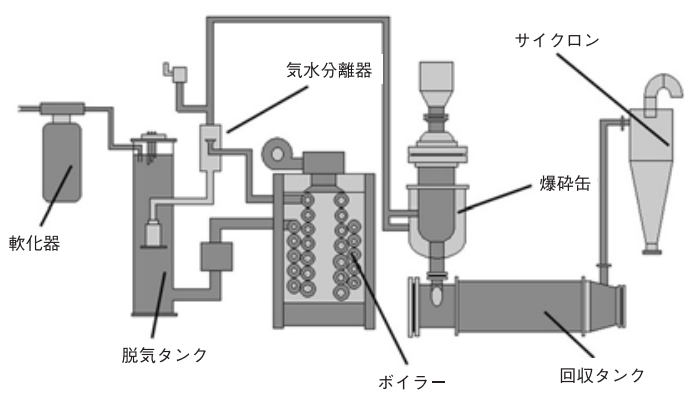

図 3 爆砕装置の概要

\section{2 供試材料}

国内に自生する代表的な樹種 5 種を供試材料とした。 供試材料は NPO 法人日本バーク堆肥協会より提供を うけた広葉樹 3 種（クヌギ: Quercus Auercus, ナ ラ: Quercus Cuspidata, サクラ: Prunus yedoensis), 針葉樹 2 種 (スギ: Cryptomeria Japonica, ヒノキ: Chamaecyparis Obtuse) とした。それぞれの樹木は一次 粉砕した (約 $\left.3 \times 4 \times 0.2 \mathrm{~cm}^{3}\right)$ 後, 風乾し水分率を測定 後，乾物換算した量を投入した。

\section{3 処理条件・分析項目}

\section{3 .1 処理条件}

処理条件は表 1 に記載した。爆砕と過熱水蒸気処理に ついては処理時の温度を $200^{\circ} \mathrm{C}$ 一定としたが, 炭化につ いては $200^{\circ} \mathrm{C}$ では風乾した投入原料に残った若干の水分 が乾燥する程度であり，炭化できないことから，処理温 度を $400^{\circ} \mathrm{C}$ とた。処理時間は, 炭化はガスの発生が加 熱開始から 45〜60 分で終了したこと, 過熱水蒸気処理 については, 馬場らの報告よりチップ化したスギを $200^{\circ} \mathrm{C} 1.95 \mathrm{MPa}, 60$ 分の処理条件で改質した際に, 最 大の発高位発熱量 $21.5 \mathrm{~kJ} / \mathrm{g}$ の改質物が得られたこと ${ }^{6)}$, 爆砕についてはまだ処理時間に関する所見が少なかった ことから，3つの処理方法の時間は60 分間に統一した。 また, それぞれの処理は炭化については 3 回, 過熱水蒸

表 1 処理条件

\begin{tabular}{|c|c|c|c|c|c|}
\hline 処理方法 & 樹種 & $\begin{array}{c}\text { 投入原料量 }{ }^{\mathrm{a})} \\
{[\mathrm{Kg}]}\end{array}$ & $\begin{array}{c}\text { 処理時の温度 } \\
{\left[{ }^{\circ} \mathrm{C}\right]}\end{array}$ & $\begin{array}{c}\text { 圧力 } \\
{[\mathrm{Mpa}]}\end{array}$ & $\begin{array}{c}\text { 処理時間 } \\
\text { [min] }\end{array}$ \\
\hline \multirow{2}{*}{ 炭化 } & 針葉樹 & \multirow{2}{*}{0.08} & \multirow{2}{*}{400} & \multirow{2}{*}{-} & \multirow{2}{*}{60} \\
\hline & 広葉樹 & & & & \\
\hline \multirow{2}{*}{ 過熱水蒸気 } & 針葉樹 & 0.8 & \multirow{2}{*}{200} & \multirow{2}{*}{1.95} & \multirow{2}{*}{60} \\
\hline & 広葉樹 & 1.6 & & & \\
\hline \multirow{2}{*}{ 爆砕 } & 針葉樹 & \multirow{2}{*}{0.5} & \multirow{2}{*}{200} & \multirow{2}{*}{1.45} & \multirow{2}{*}{60} \\
\hline & 広葉樹 & & & & \\
\hline
\end{tabular}

a）乾物の重さ
気処理，爆砕については 5 回繰り返し実験を行った。

\section{3 .2 分析方法}

(1) 木材成分の分析方法

木材を構成している成分は主成分と副成分に大別され る。主成分はセルロース，ヘミセルロース，リグニンか らなり, 副成分は脂肪族化合物, 芳香族化合物, テルペ ン類などのアルコール・ベンゼンで抽出できる成分と灰 分からなる。セルロースは木材組成中の約 40〜 $50 \%$ を 占め, セルロースは D-グルコースが $\beta-1,4$ グルコシド 結合した長鎖状のホモポリマーで特有の結晶構造を持っ ており, アルカリ溶解や酸加水分解に対する抵抗性は比 較的に強い。セルロースは工業的に加水分解するとグル コースになる。へミセルロースは木材組成分中の約 15〜35\%を占める非セルロース系の多糖類であり，加 水分解するとキシロース, アラビノース, グルコース, マンノース, ガラクトース, ウロン酸, 酢酸等を生じる。 続いて, リグニンは多糖類とともに植物体の骨格を構成 している物質で，木材では約 18～35\% 含有している。 リグニンはフェノール性の物質で通常植物の成育につれ て合成され組織を強固にする役割を果たす7)。リグニン はセルロースやへミセルロースが酸によって構成糖に分 解されるのと異なり, 酸によって構成フェニールプロパ ン構造単位に分解することはできない。

本研究では, 処理後の試料の水分 (重量法) を測定後, 乾燥させたものをミキサーで粉砕したものをサンプルと した。セルロースとへミセルロースを合わせたホロセル ロース（亚塩素酸ナトリウム一酢酸法）とリグニン (72\% 硫酸処理残椬（Klason リグニンとして表示）： Klason 法), 副成分である抽出成分 (アルコール・ベン ゼン抽出物：JIS P8010-76）と灰分（電気マッフル炉 法）の分析を行った。アルコール・ベンゼン抽出物には 脂肪族化合物, テルペン類の他, セルロースやヘミセル ロースから分解して生じるグルコールやキシロースなど の糖類も抽出される。つまり，ホロセルロースが減少し， アルコール・ベンゼン抽出物が増加すれば分解が進んだ ことの証明となる。よって。これらを分析することによ り，3つの処理を行った木材がどのようにその成分を変 化させるのか明らかにした。

(2) 元素分析

全炭素と全水素（酸素循環燃焼方式 $\mathrm{NCH}$ アナライ ザー（侏住化分析センター製 SUMIGRAPH NCH-22F)） を測定することで炭素化の進行を明らかにした。

\section{(3) 工業分析}

発熱量：燃研式自動ボンベ高位発熱量計（株島津製作 所：(CA-4AJ), 工業分析は石炭・コークス類の工業分析 法 JIS M 8812 （1963）に準じて行った。 


\section{4. 実 験 結 果}

\section{1 収率}

表 2 に炭化・過熱水蒸気処理 - 爆砕の原料投入重量 (乾物) に対する処理後乾燥物の回収重量（以下：収率 とする）を記載した。

炭化と過熱水蒸気処理は, 処理後に投入した木質バイ オマスが乾燥した状態もしくは水分が少なくなった状態 で回収できるのに対し，爆砕は処理後の木質バイオマス に多量の水分を含んだものが回収された。特に，広葉樹 を原料として爆砕をした場合, 多量の水分を処理後の試

表 2 炭化・過熱水蒸気処理 ·爆砕の収率

\begin{tabular}{|c|c|c|c|c|c|c|}
\hline $\begin{array}{l}\text { 処理 } \\
\text { 方法 }\end{array}$ & 樹種 & $\begin{array}{c}\text { 原料投入量 }^{\text {a) }} \\
{[\mathrm{kg}]}\end{array}$ & $\begin{array}{c}\text { 処理後 } \\
{[\mathrm{kg}]}\end{array}$ & $\begin{array}{l}\text { 処理 } \\
{[\mathrm{kg}]}\end{array}$ & $\begin{array}{l}\text { 後乾燥物 } \\
\text { 標準偏差 }\end{array}$ & $\begin{array}{c}\text { 収率 } \\
\%\end{array}$ \\
\hline & 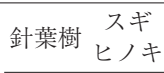 & $\begin{array}{l}0.08 \\
0.08\end{array}$ & $\begin{array}{l}0.03 \\
0.03\end{array}$ & $\begin{array}{l}0.03 \\
0.03\end{array}$ & $\begin{array}{l}0.000 \\
0.000\end{array}$ & $\begin{array}{l}32.4 \\
31.2\end{array}$ \\
\hline $\begin{array}{l}\text { 存 } \\
\text { 化 }\end{array}$ & $\begin{aligned} & \text { ナラ } \\
& \text { 広葉樹 クヌギ } \\
& \text { サクラ }\end{aligned}$ & $\begin{array}{l}0.08 \\
0.08 \\
0.08\end{array}$ & $\begin{array}{l}0.02 \\
0.02 \\
0.03\end{array}$ & $\begin{array}{l}0.02 \\
0.02 \\
0.03\end{array}$ & $\begin{array}{l}0.001 \\
0.001 \\
0.000\end{array}$ & $\begin{array}{l}28.1 \\
28.8 \\
29.5\end{array}$ \\
\hline $\begin{array}{l}\text { 過 } \\
\text { 熱 }\end{array}$ & 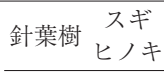 & $\begin{array}{l}0.8 \\
0.8\end{array}$ & $\begin{array}{l}0.77 \\
0.70\end{array}$ & $\begin{array}{l}0.70 \\
0.67\end{array}$ & & $\begin{array}{l}86.9 \\
83.6\end{array}$ \\
\hline $\begin{array}{l}\text { 永 } \\
\text { 䒱 } \\
\text { 穿 }\end{array}$ & $\begin{aligned} & \text { ナラ } \\
& \text { 広葉樹 クヌギ } \\
& \text { サクラ }\end{aligned}$ & $\begin{array}{l}1.6 \\
1.6 \\
1.6 \\
\end{array}$ & $\begin{array}{l}1.54 \\
1.59 \\
1.42 \\
\end{array}$ & $\begin{array}{l}1.26 \\
1.22 \\
1.27 \\
\end{array}$ & $\begin{array}{l}0.012 \\
0.042 \\
0.006 \\
\end{array}$ & $\begin{array}{l}79.0 \\
76.1 \\
79.1 \\
\end{array}$ \\
\hline & 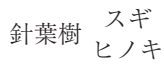 & $\begin{array}{l}0.5 \\
0.5\end{array}$ & $\begin{array}{l}0.44 \\
1.29\end{array}$ & $\begin{array}{l}0.34 \\
0.42\end{array}$ & $\begin{array}{l}0.003 \\
0.004\end{array}$ & $\begin{array}{l}68.5 \\
83.9\end{array}$ \\
\hline 臀 & $\begin{array}{c}\text { ナラ } \\
\text { 広葉樹 クヌギ } \\
\text { サクラ }\end{array}$ & $\begin{array}{l}0.5 \\
0.5 \\
0.5\end{array}$ & $\begin{array}{l}1.15 \\
1.71 \\
1.30\end{array}$ & $\begin{array}{l}0.40 \\
0.35 \\
0.39\end{array}$ & $\begin{array}{l}0.002 \\
0.004 \\
0.005\end{array}$ & $\begin{array}{l}79.6 \\
70.6 \\
77.5\end{array}$ \\
\hline
\end{tabular}

料に含有して㧍り，非常にハンドリングが悪かった。

続いて, 原料投入重量に対する処理固形物の収率は, 樹種によって違いがあるが, 炭化は 28～32\%, 過熱水 蒸気処理は 76 87\%, 爆砕は 65～83\% であり, 過熱水 蒸気処理・爆砕は炭化と同様に針葉樹の方が広葉樹に比 べて収率が高い結果となった。3つの処理方法を比較す ると，炭化の収率が低い結果となり，処理による損失が 多いことが明らかとなった。

針葉樹よりも広葉樹の方が, 収率が低かった理由とし て, 針葉樹材は広葉樹材と比較し, 化学的に複雑な構造 をしている ${ }^{8}$ ということと，また蒸煮・爆砕に抢いても スギなどの針葉樹材は広葉樹材に比べて分解されにく ( ${ }^{9)}$ ことが報告されており，針葉樹の方が分解されず固 体収率が高かったことが考えられる。

\section{2 分析結果}

\section{2 .1 木材成分の分析結果}

処理前の試料㧍よび処理物の分析結果を表 3 に記載し た。

まず，炭化では，アルコール・ベンゼン抽出物・ホロ セルロースは検出されず，その一方 Klason リグニンの 值が高かった。これは，アルコール・ベンゼン抽出物や ホロセルロースが分解し，Klasonリグニンが分解され ず残存したため, Klason リグニンの全体を占める割合 が高くなったためである。

続いて, 過熱水蒸気処理ではアルコール・ベンゼン

a）乾物の重さ

表 3 処理物の分析結果*

\begin{tabular}{|c|c|c|c|c|c|c|}
\hline 処理方法 & \multicolumn{2}{|c|}{ 樹種 } & $\begin{array}{c}\text { アルコールベンゼン抽出物 } \\
{[\%]}\end{array}$ & $\begin{array}{l}\text { 灰分 } \\
{[\%]}\end{array}$ & $\begin{array}{c}\text { ホロセルロース } \\
{[\%]}\end{array}$ & $\begin{array}{c}\text { Klason リグニン } \\
{[\%]}\end{array}$ \\
\hline \multirow[b]{2}{*}{ 処理前試料 } & 針葉樹 & $\begin{array}{l}\text { スギ } \\
\text { ヒノキ }\end{array}$ & \begin{tabular}{|l}
2.5 \\
3.6
\end{tabular} & $\begin{array}{l}0.6 \\
0.3\end{array}$ & $\begin{array}{l}52.3 \\
57.0\end{array}$ & $\begin{array}{l}34.8 \\
32.4\end{array}$ \\
\hline & 広葉樹 & $\begin{array}{c}\text { ナラ } \\
\text { クヌギ } \\
\text { サクラ }\end{array}$ & $\begin{array}{l}1.0 \\
1.0 \\
3.3 \\
\end{array}$ & $\begin{array}{l}0.6 \\
0.9 \\
0.4\end{array}$ & $\begin{array}{l}60.8 \\
61.2 \\
62.8 \\
\end{array}$ & $\begin{array}{l}24.3 \\
33.3 \\
34.1 \\
\end{array}$ \\
\hline \multirow[b]{2}{*}{ 炭化 } & 針葉樹 & $\begin{array}{l}\text { スギ } \\
\text { ヒノキ }\end{array}$ & $\begin{array}{l}\text { trace } \\
\text { trace }\end{array}$ & $\begin{array}{l}1.2 \\
1.1\end{array}$ & $\begin{array}{l}\text { trace } \\
\text { trace }\end{array}$ & $\begin{array}{l}99.0 \\
96.8\end{array}$ \\
\hline & 広葉樹 & $\begin{array}{c}\text { ナラ } \\
\text { クヌギ } \\
\text { サクラ }\end{array}$ & $\begin{array}{l}\text { trace } \\
\text { trace } \\
\text { trace }\end{array}$ & $\begin{array}{l}1.7 \\
2.3 \\
1.2\end{array}$ & $\begin{array}{l}\text { trace } \\
\text { trace } \\
\text { trace }\end{array}$ & $\begin{array}{r}97.4 \\
97.8 \\
100.0\end{array}$ \\
\hline \multirow[b]{2}{*}{ 過熱水蒸気 } & 針葉樹 & $\begin{array}{l}\text { スギ } \\
\text { ヒノキ }\end{array}$ & $\begin{array}{l}5.1 \\
1.7\end{array}$ & $\begin{array}{l}0.7 \\
0.1\end{array}$ & $\begin{array}{l}47.8 \\
51.6\end{array}$ & $\begin{array}{l}46.0 \\
43.2 \\
\end{array}$ \\
\hline & 広葉樹 & $\begin{array}{c}\text { ナラ } \\
\text { クヌギ } \\
\text { サクラ }\end{array}$ & $\begin{array}{r}10.1 \\
14.2 \\
7.6\end{array}$ & $\begin{array}{l}0.6 \\
0.9 \\
0.2\end{array}$ & $\begin{array}{l}56.3 \\
43.2 \\
50.9\end{array}$ & $\begin{array}{l}31.8 \\
40.4 \\
42.6\end{array}$ \\
\hline \multirow[b]{2}{*}{ 爆砕 } & 針葉樹 & $\begin{array}{l}\text { スギ } \\
\text { ヒノキ }\end{array}$ & $\begin{array}{l}5.4 \\
3.8\end{array}$ & $\begin{array}{l}0.3 \\
0.1\end{array}$ & $\begin{array}{l}49.8 \\
51.2\end{array}$ & $\begin{array}{l}44.7 \\
42.2\end{array}$ \\
\hline & 広葉樹 & $\begin{array}{c}\text { ナラ } \\
\text { クヌギ } \\
\text { サクラ }\end{array}$ & $\begin{array}{r}8.8 \\
12.9 \\
7.2\end{array}$ & $\begin{array}{l}0.3 \\
0.6 \\
0.3\end{array}$ & $\begin{array}{l}60.9 \\
58.4 \\
57.1\end{array}$ & $\begin{array}{l}26.8 \\
25.3 \\
36.8\end{array}$ \\
\hline
\end{tabular}

※ 分析結果は乾燥試料の分析值で記載 
抽出物が増加し, 特に広葉樹の場合, その増加がより顕 著であった。また, ホロセルロースが減少した。特に, クヌギとサクラで大きく減少した。難分解性物質である Klason リグニンは炭化処理ほどではないが高かった。 これも炭化同様にホロセルロースの分解が進み, Klason リグニンの多くが分解されず残ったためと考え られる。

爆砕ではアルコール・ベンゼン抽出物の量が増加した。 こちらも過熱水蒸気処理と同様に, 広葉樹の方がアル コール・ベンゼン抽出物の量が多かった。ホロセルロー スはナラ以外では減少したが, 過熱水蒸気処理ほどは減 少しなかった。また，針葉樹を原料とした場合は Klason リグニンが増加し，広葉樹を原料とした場合は クヌギのみ減少していた。

炭化物のアルコール・ベンゼン抽出物やホロセルロー スが検出されなかった理由として, ペントザンと $\gamma$-セ

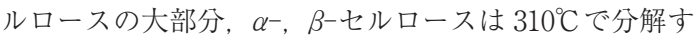
ること ${ }^{10)}$ が栗山により報告されており，本研究で用いた 炭化の温度が $400^{\circ} \mathrm{C}$ であったため, アルコール・ベンゼ ン抽出物およびホロセルロースが分解し, 検出されな かったことが考えられる。

過熱水蒸気処理・爆砕において針葉樹におけるアル コール・ベンゼン抽出物が広葉樹と比較して少なかった 理由として, 針葉樹材は広葉樹材と比較し, 化学的に複 雑な構造をしていること朁によって, 針葉樹材を原料と
した場合に分解が進まなかったと考えられる。

\section{2 .2 元素分析.工業分析結果}

元素分析・工業分析結果を表 4 に記載した。

炭化物の主成分は炭素であり, その炭素の大部分が固 定炭素であった。水素と酸素は大幅に減少した。

過熱水蒸気処理と爆砕の元素組成に炭化ほどの大きな 変化は見られず，水素 5.4〜 5.7\% に，酸素が 41.2～43.9\% に減少し，炭素が50.7〜 53.1\%に増加した。

過熱水蒸気処理をした木質バイオマスの工業分析では, 揮発成分が 75.0 ～78.2\% に減少し，固定炭素が 21.6〜 $24.2 \%$ に増加した。爆砕の固定炭素は過熱水蒸気処理に 比べて少なかった。

4.2 .3 処理前試料の各成分含有量と処理後の回収量

図 4 に, 表 2 と表 3 の結果より算出した処理前の原料 $1 \mathrm{~kg}$ に含有する成分と, 原料 $1 \mathrm{~kg}$ 処理した場合の処理 後の各成分量を示した。

アルコール・ベンゼン抽出物は広葉樹のナラとクヌギ を原料とした過熱水蒸気処理・爆砕で大幅に増加し, サ クラでも増加が見られた。

続いて, ホロセルロースは炭化するとなくなり, 過熱 水蒸気処理・爆砕もホロセルロースの分解が進むが, 炭 化ほどの分解はしなかった。

Klason リグニンは広葉樹を原料とした爆砕処理で減 少が見られたが, その他のものについては大きな変化は 見られなかった。またスギ・ヒノキを原料とした過熱水

表 4 原料および処理物の元素分析・工業分析結果

\begin{tabular}{|c|c|c|c|c|c|c|c|c|}
\hline \multirow[b]{2}{*}{ 処理方法 } & \multirow{2}{*}{\multicolumn{2}{|c|}{ 樹種 }} & \multicolumn{3}{|c|}{ 元素組成 } & \multicolumn{3}{|c|}{ 工業分析 } \\
\hline & & & \multirow{2}{*}{$\begin{array}{c}\begin{array}{c}\mathrm{C} \\
{[\%]}\end{array} \\
50.5 \\
48.3\end{array}$} & \multirow{2}{*}{$\begin{array}{c}\begin{array}{c}\mathrm{H} \\
{[\%]}\end{array} \\
6.0 \\
5.8\end{array}$} & \multirow{2}{*}{$\begin{array}{l}\begin{array}{l}\mathrm{O}^{\text {a) }} \\
{[\%]}\end{array} \\
43.5 \\
45.9\end{array}$} & \multirow{2}{*}{$\begin{array}{l}\begin{array}{c}\text { 灰分 } \\
{[\%]}\end{array} \\
0.6 \\
0.3\end{array}$} & \multirow{2}{*}{$\begin{array}{c}\text { 揮発分 } \\
{[\%]}\end{array}$} & \multirow{2}{*}{$\begin{array}{c}\begin{array}{c}\text { 固定炭素b) } \\
{[\%]}\end{array} \\
15.7 \\
13.2\end{array}$} \\
\hline & 針葉樹 & $\begin{array}{c}\text { スギ } \\
\text { ヒノキ }\end{array}$ & & & & & & \\
\hline 処理前試料 & 広葉樹 & $\begin{array}{l}\text { ナラ } \\
\text { クヌギ } \\
\text { サクラ }\end{array}$ & $\begin{array}{l}46.8 \\
45.9 \\
47.6\end{array}$ & $\begin{array}{l}6.0 \\
6.0 \\
5.9\end{array}$ & $\begin{array}{l}47.2 \\
48.0 \\
46.4\end{array}$ & $\begin{array}{l}0.6 \\
0.9 \\
0.4\end{array}$ & $\begin{array}{l}87.7 \\
85.4 \\
87.0\end{array}$ & $\begin{array}{l}11.7 \\
13.7 \\
12.6\end{array}$ \\
\hline \multirow[b]{2}{*}{ 炭化 } & 針葉樹 & $\begin{array}{c}\text { スギ } \\
\text { ヒノキ }\end{array}$ & $\begin{array}{l}73.5 \\
75.0\end{array}$ & $\begin{array}{l}3.7 \\
3.9\end{array}$ & $\begin{array}{l}22.8 \\
21.1\end{array}$ & $\begin{array}{l}1.2 \\
1.1\end{array}$ & $\begin{array}{l}32.2 \\
33.6\end{array}$ & $\begin{array}{l}66.6 \\
65.3\end{array}$ \\
\hline & 広葉樹 & $\begin{array}{l}\text { ナラ } \\
\text { クヌギ } \\
\text { サクラ }\end{array}$ & $\begin{array}{l}72.7 \\
73.3 \\
73.0\end{array}$ & $\begin{array}{l}3.6 \\
3.8 \\
3.7\end{array}$ & $\begin{array}{l}23.8 \\
23.0 \\
23.3\end{array}$ & $\begin{array}{l}1.7 \\
2.3 \\
1.2\end{array}$ & $\begin{array}{l}31.8 \\
32.7 \\
34.0\end{array}$ & $\begin{array}{l}66.5 \\
65.0 \\
64.7\end{array}$ \\
\hline \multirow[b]{2}{*}{ 過熱水蒸気 } & 針葉樹 & $\begin{array}{c}\text { スギ } \\
\text { ヒノキ }\end{array}$ & $\begin{array}{l}53.1 \\
53.0\end{array}$ & $\begin{array}{l}5.7 \\
5.5\end{array}$ & $\begin{array}{l}41.2 \\
41.5\end{array}$ & $\begin{array}{l}0.7 \\
0.1\end{array}$ & $\begin{array}{l}75.1 \\
78.2\end{array}$ & $\begin{array}{l}24.2 \\
21.6\end{array}$ \\
\hline & 広葉樹 & $\begin{array}{l}\text { ナラ } \\
\text { クヌギ } \\
\text { サクラ }\end{array}$ & $\begin{array}{l}50.7 \\
52.9 \\
50.7 \\
\end{array}$ & $\begin{array}{l}5.5 \\
5.6 \\
5.4 \\
\end{array}$ & $\begin{array}{l}43.8 \\
41.5 \\
43.9 \\
\end{array}$ & $\begin{array}{l}0.6 \\
0.9 \\
0.2\end{array}$ & $\begin{array}{l}77.0 \\
75.0 \\
75.6\end{array}$ & $\begin{array}{l}22.4 \\
24.0 \\
24.1 \\
\end{array}$ \\
\hline \multirow[b]{2}{*}{ 爆砕 } & 針葉樹 & $\begin{array}{c}\text { スギ } \\
\text { ヒノキ }\end{array}$ & $\begin{array}{l}52.2 \\
49.9 \\
\end{array}$ & $\begin{array}{l}5.5 \\
5.5 \\
\end{array}$ & $\begin{array}{l}42.2 \\
44.6 \\
\end{array}$ & $\begin{array}{l}0.3 \\
0.1\end{array}$ & $\begin{array}{l}80.6 \\
81.7\end{array}$ & $\begin{array}{l}19.1 \\
18.2 \\
\end{array}$ \\
\hline & 広葉樹 & $\begin{array}{c}\text { ナラ } \\
\text { クヌギ } \\
\text { サクラ }\end{array}$ & $\begin{array}{l}48.2 \\
48.3 \\
52.5\end{array}$ & $\begin{array}{l}5.6 \\
5.6 \\
5.4\end{array}$ & $\begin{array}{l}46.2 \\
46.0 \\
42.1\end{array}$ & $\begin{array}{l}0.3 \\
0.6 \\
0.3\end{array}$ & $\begin{array}{l}84.9 \\
81.9 \\
82.2\end{array}$ & $\begin{array}{l}14.8 \\
17.5 \\
17.5\end{array}$ \\
\hline
\end{tabular}

a) 100 - (炭素含有量 + 水素含有量 $)=$ 酸素含有量（\%）により計算

b) $100-($ 灰分十揮発分 $)=$ 固定炭素（\%)により計算 


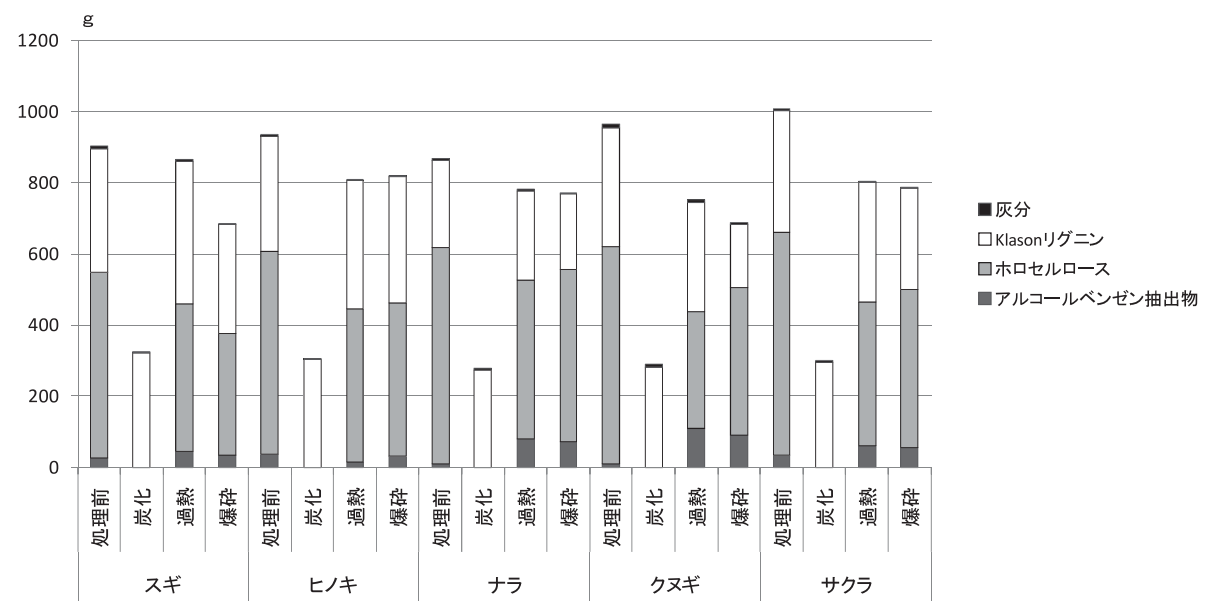

*図 4 は表 $2 ， 3$ を元に算出した

※炎処理前は原料 $1 \mathrm{~kg}$ に含まれるそれぞれの成分量を記載した

*洋処理物は処理後の成分量に収率を乗じ，原料 $1 \mathrm{~kg}$ から回収できた成分量を記載した

図 4 処理前試料の各成分含有量と処理後の各成分回収量 $*$ ※) ***)

蒸気処理では Klason リグニンは増加した。

炭化の場合, $310^{\circ} \mathrm{C}$ ま゙はリグニンの分解はごくわず かであり，多量の残存リグニンに加え，ヘミセルロース およびセルロースの分解残さ, すなわち炭素分の多く なった固体生成物がリグニンに加わること初が報告され ており，スギ・ヒノキを原料とした過熱水蒸気処理で Klason リグニンが増加したのは, 針葉樹が広葉樹に比 べ分解しにくいのに加え，これと同様のことが起きたの ではないかと考えられる。

\section{3 処理物の発熱量と処理における炭素の損失}

\subsubsection{MJ のエネルギー製造に必要な木材量}

表 5 に，処理物の発熱量と，10 MJ の熱量を製造する ために必要な処理物の量と原料木材の量を記載した。

炭化は発熱量が 29,148〜29,783 J/g であり, 最も重量 あたりの発熱量が高く品質が良い燃料の製造ができた。 続いて, 過熱水蒸気処理が 20,326 21,821 J/g で, 爆砕 が 19,221〜21,055 J/g であった。過熱水蒸気処理や爆砕 は炭化に比べ発熱量が低く，質の良い燃料が製造できな かった。同じ $10 \mathrm{MJ}$ の然料を必要とする場合, 必要な 処理物の量は, 炭化は 336 343 g, 過熱水蒸気処理は

表 5 処理物の発熱量と $10 \mathrm{MJ}$ の処理物を製造するのに必要な原料量

\begin{tabular}{|c|c|c|c|c|c|c|}
\hline 処理方法 & \multicolumn{2}{|c|}{ 樹種 } & \multirow{2}{*}{$\begin{array}{c}\text { 発熱量a) } \\
{[\mathrm{KJ} / \mathrm{kg}]}\end{array}$} & \multirow{2}{*}{$\begin{array}{l}\begin{array}{l}\text { 収率 } \\
\text { [\%] }\end{array} \\
32.4 \\
31.2 \\
\end{array}$} & \multirow{2}{*}{$\begin{array}{c}10 \mathrm{MJ} \text { の処理物量 } \\
{[\mathrm{kg}]}\end{array}$} & \multirow{2}{*}{$\begin{array}{c}10 \mathrm{MJ} \text { の処理物を } \\
\text { 製造する際の原料量 } \\
{[\mathrm{kg}]} \\
1.05 \\
1.10\end{array}$} \\
\hline & 針葉樹 & $\begin{array}{c}\text { スギ } \\
\text { ヒノキ }\end{array}$ & & & & \\
\hline 炭化 & 広葉樹 & $\begin{array}{l}\text { ナラ } \\
\text { クヌギ } \\
\text { サクラ }\end{array}$ & $\begin{array}{l}29,605 \\
29,783 \\
29,553\end{array}$ & $\begin{array}{l}28.1 \\
28.8 \\
29.5 \\
\end{array}$ & $\begin{array}{l}0.34 \\
0.34 \\
0.34 \\
\end{array}$ & $\begin{array}{l}1.20 \\
1.16 \\
1.15\end{array}$ \\
\hline \multirow[b]{2}{*}{ 過熱水蒸気 } & 針葉樹 & $\begin{array}{c}\text { スギ } \\
\text { ヒノキ }\end{array}$ & $\begin{array}{l}21,821 \\
21,477 \\
\end{array}$ & $\begin{array}{l}86.9 \\
83.6 \\
\end{array}$ & $\begin{array}{l}0.46 \\
0.47 \\
\end{array}$ & $\begin{array}{l}0.53 \\
0.56 \\
\end{array}$ \\
\hline & 広葉樹 & $\begin{array}{l}\text { ナラ } \\
\text { クヌギ } \\
\text { サクラ }\end{array}$ & $\begin{array}{l}20,326 \\
20,981 \\
21,560\end{array}$ & $\begin{array}{l}79.0 \\
76.1 \\
79.1 \\
\end{array}$ & $\begin{array}{l}0.49 \\
0.48 \\
0.46\end{array}$ & $\begin{array}{l}0.62 \\
0.63 \\
0.59\end{array}$ \\
\hline \multirow[b]{2}{*}{ 爆砕 } & 針葉樹 & $\begin{array}{c}\text { スギ } \\
\text { ヒノキ }\end{array}$ & $\begin{array}{l}21,055 \\
20,641\end{array}$ & $\begin{array}{l}68.5 \\
83.9\end{array}$ & $\begin{array}{l}0.47 \\
0.48\end{array}$ & $\begin{array}{l}0.69 \\
0.58\end{array}$ \\
\hline & 広葉樹 & $\begin{array}{l}\text { ナラ } \\
\text { クヌギ } \\
\text { サクラ }\end{array}$ & $\begin{array}{l}19,221 \\
19,833 \\
19,996\end{array}$ & $\begin{array}{l}79.6 \\
70.6 \\
77.5\end{array}$ & $\begin{array}{l}0.52 \\
0.50 \\
0.50\end{array}$ & $\begin{array}{l}0.65 \\
0.71 \\
0.64\end{array}$ \\
\hline
\end{tabular}

a）高位発熱量を記載 
表 6 炭素残存率と炭素損失率

\begin{tabular}{|c|c|c|c|c|c|c|c|c|}
\hline \multirow{3}{*}{\multicolumn{2}{|c|}{ 樹種 }} & \multirow{2}{*}{ 処理前試料 } & \multicolumn{3}{|c|}{ 炭素残存率a) } & \multicolumn{3}{|c|}{ 炭素損失率b) } \\
\hline & & & 炭化 & 過熱水蒸気 & 爆砕 & 炭化 & 過熱水蒸気 & 爆砕 \\
\hline & & \multicolumn{4}{|c|}{$[\%]$} & \multicolumn{3}{|c|}{ [\%] } \\
\hline \multirow{2}{*}{ 針葉樹 } & スギ & 50.5 & 23.8 & 46.2 & 35.8 & 52.7 & 8.5 & 29.0 \\
\hline & ヒノキ & 48.3 & 23.4 & 44.3 & 41.8 & 51.6 & 8.3 & 13.5 \\
\hline \multirow{3}{*}{ 広葉樹 } & ナラ & 46.8 & 20.4 & 40.1 & 38.3 & 56.5 & 14.5 & 18.1 \\
\hline & クヌギ & 45.9 & 21.1 & 40.3 & 34.1 & 54.1 & 12.3 & 25.7 \\
\hline & サクラ & 47.6 & 21.5 & 40.1 & 40.7 & 54.8 & 15.8 & 14.5 \\
\hline
\end{tabular}

a）数值はすべて表 2 と表 5 を使用し, 絶乾処理前木材試料重に対する％として計算

b) 処理後の残存炭素 $\div$ 処理前試料の炭素 $\times 100$

458 492 g, 爆砕で 475 520 g であり, 過熱水蒸気処 理では炭化の 1.3 倍, 爆砕では 1.5 倍の処理物が必要と なる。しかし, 過熱水蒸気処理や爆砕は処理時の収率が 高いため, $10 \mathrm{MJ}$ の処理物を製造するために必要な原料 木材の量は過熱水蒸気処理で炭化の半分の量, 爆砕で $60 \%$ 程度の量と推計された。

\section{3 .2 処理に打ける炭素の損失}

表 6 に炭素の残存率と損失率を記載した。炭化が炭素 の損失が最も大きく, 原料樹木が元々含有している炭素 の $50 \%$ しか処理物に残存していなかった。また, 針葉 樹に比べ広葉樹の方が炭素の損失が大きかった。前処理 に㧍ける炭素の損失が最も少なかったのが過熱水蒸気処 理で, 針葉樹を原料とした場合, 約 $8 \%$, 広葉樹を原料 とした場合 12〜16\% であった。過熱水蒸気処理は原料 樹木が持っている炭素の大部分を残存しており, 炭素を 有効に利用できると考えられる。

\section{5. 考察}

温度 $400^{\circ} \mathrm{C}$, 処理時間 60 分で木材を炭化した場合は, 蒸気温度 $200^{\circ} \mathrm{C}$, 処理時間 60 分で爆砕もしくは過熱水 蒸気処理を行った場合と比べて, アルコール・ベンゼン 抽出物やホロセルロースが大きく減少し, 炭化物の固定 炭素が上がり, 重量あたりの発熱量が大きい燃料が製造 できる。しかし, 爆砕・過熱水蒸気処理に比べて, 炭素 の損失が極めて大きい処理であることが示された。過熱 水蒸気処理は, 固定炭素量が増加し, 発熱量も高くなる が, 燃料として炭化処理をした木材ほど燃料としての質 は高くない結果となった。しかし, 樹木中の炭素を有効 に利用する場合, 過熱水蒸気処理は炭素の損失が少なく 適していると考えられる。爆砕は, 木材の組織を崩壊・ 繊維化させ有用物質の抽出によく用いる技術であるため, ホロセルロースやリグニンなどの含有量に変化がみられ ることを期待したが, 蒸気温度 $200^{\circ} \mathrm{C}$, 処理時間 60 分
で爆砕した場合は, 過熱水蒸気処理した場合と比較し木 材成分は大きな変化は見られなかった。

現在, 木質バイオマスは, 暖房・調理用の燃料や, 活 性炭, 工業用, 土畩改良用に利用されており, 特に炭化 物の利用については，土潩改良としての利用率が高い。

近年, 農林水産省が, 地球温暖化対策の次期枠組み (ポスト京都議定書)に向けての国際交渉において,「日 本は, 二酸化炭素など温室効果ガス吸収源のひとつとし て農地土壤を提言する」方針を固め, 炭化物を土壤に埋 設し，土壤を炭素の吸収源とする動きがある。国際的に もデンマーク, カナダ, ポルトガル, スペインが農地土 壤を吸収源として選択している。農水省の調査では, 日 本の農地全体が吸収源と認定された場合, 京都議定書で の国際約束 $\mathrm{CO}_{2}$ 削減分の 1 割にも達するという。

農地に投入する炭は分解が遅いため, 土壤に投入すれ ばその大部分が農地に貯留することになる。しかし，炭 は元々樹木が持っていた炭素の $50 \%$ 前後しか炭素を保 持して扔らず，残りの $50 \%$ は炭の製造過程に扔いて木 酢液や大気に二酸化炭素として放出されており, 炭素の 損失が非常に大きい。そこで, 樹木炭素の $90 \%$ を保持 する過熱水蒸気処理した木材を土壤に埋没すれば樹木が 元々もっている炭素の損失を少なくし, かつ, その主成 分は難分解のホロセルロースやリグニンであり, 原料の 樹木より分解が遅いため安定した状態で土壤に供給する ことができると考えられる。また，過熱水蒸気処理した 木材は炭素化と同時に乾燥ができる点, そして木材の形 状がもろくなることから加工が容易であるため, ペレッ ト化すれば，ハンドリングや作業効率も上がり有効に利 用できると考えられる。

しかし, 過熱水蒸気処理や爆砕は水を水蒸気の状態ま で加熱する必要があり, 炭化に比べ, 製造コストが一般 的に高いこと，処理をする際の燃料投入量が多いことに ついては検討が必要になると考えられる。 
[謝 辞 $]$

試験実施にあたり，サンプルを提供していただい た NPO 法人日本バーク堆肥協会の皆様方に対し, 感謝の意を表します。

参 考文 献

1) 社日本エネルギー学会: バイオマスハンドブック, オーム社, pp. 24-28(2002)

2 ) 谷田貝光克：木炭の特性とその利用，木材工業，第 52 巻, 第 10 号, pp. 472-477 (1997)

3 ) 凌祥之, 柬理 裕: バイオマス由来の炭化物の用途開 発と炭化装置の改良，農業抢よび園芸，第 78 巻，第 10 号, pp. 1049-1055（2003）

4 ）侏エヌ・ティー・エス：過熱水蒸気技術集成—その 特性と拡がる最新利用および装置開発の現状——, p 4 (2005)

5 ）棚橋光彦：爆砕法による森林バイオマスの変換と総合
利用，木材研究，第 18 巻，pp. 34-65 (1983)

6 ）馬場竜介, 飯島倫明, 大林宏也, 牧恒雄: 木質バイ オマスのエネルギー化に関する基礎的研究, 日本エ ネルギー学会大体講演要旨集, 第 15 卷, pp. 245-246 (2006)

7 ) 城代 進, 鮫島一彦: 木材科学講座 4 化学, 海青社, pp. 15-19 (1993)

8 ) O. Bobleter: Hydrothermal Degradation of Polymers Derived from Plants, Prog. Polym. Sci., Vol. 19, No. 5, pp. 797-841 (1994)

$9)$ M. Goto, T. Noda, A. Ogata, A. Komada and A. Hirose : Supercritical Water Oxidation by Hydrogen Peroxide for Destruction of Alcohol Distillery Wastewater and Municipal Sludge, The $4^{\text {th }}$ International Symposium on Supercritical Fluids, Japan, May, Vol. A, 91 (1997)

10）栗山 旭：木材の炭化過程に関する研究, 林試研報, 第 304 号, pp. 7-76 (1979)

\title{
The Study of Chemical Composition Change in Systems using Carbonization, Superheated Steam and Blasting for Wood Biomass
}

\author{
Akiko Matsunaga*, Ryo Onishi*, Mami Irie*, Takenori Yamaguchi* \\ and Akikuni Ushikubo* \\ * Tokyo University of Agriculture \\ ** Graduate School of Life and Environmental Science, Osaka Prefecture University \\ and NPO eco design network \\ ${ }^{\dagger}$ Correspondence should be addressed to Akiko Matsunaga: \\ Tokyo University of Agriculture \\ (1-1-1 Sakuragaoka, Setagaya-ku, Tokyo 156-8502 Japan)
}

\begin{abstract}
It has been suggested that carbonization systems, superheated steam systems and blasting systems are effective for the utilization of wood biomass resources. However, there are few studies comparing these processes. Therefore this study investigated these three types of systems.

A carbonization system using $400^{\circ} \mathrm{C}$ steam for 60 minutes had reduced alcohol-benzene extract and holocellulose, and it produced high-calorie fuel because the carbon fixation rate increased. However, of the three types of systems, the carbonization lost the most carbon from the materials. The superheated steam system and the blasting system with $200^{\circ} \mathrm{C}$ steam for 60 minutes had increased alcoholic-benzene extract for broadleaf trees and had slightly decreased holocellulose. The blasting system could decrease ash. The heat capacity of the superheated steamed material and the blasted material were lower than the charcoal, and their fuel qualities were lower. However, the carbon losses by these processes were much lower than by carbonization. Therefore, a superheated steam system could be a suitable method for the utilization of carbon fixed in wood.
\end{abstract}

Keywords : carbonization system, superheated steam system, blasting system, wood biomass, carbon budget 